\title{
Financial constraints in China: Firm-level evidence
}

\author{
Sandra PONCET ${ }^{\mathrm{a}, \mathrm{b}}$, Walter STEINGRESS ${ }^{\mathrm{c}}$, Hylke VANDENBUSSCHE ${ }^{\mathrm{d}, *}$ \\ a Paris School of Economics (Université Paris 1), France \\ b CEPII, France \\ c Boston University, USA \\ ' Université catholique de Louvain, CORE, B-1348 Louvain-la-neuve, Belgium
}

\section{A R T I C L E I N F O}

\section{Article history:}

Received 4 March 2009

Received in revised form 18 February 2010

Accepted 8 March 2010

Available online $\mathrm{xxxx}$

\section{JEL classification:}

E22

G32

Keywords:

Investment-cash flow sensitivity

China

Firm-level data

Foreign direct investment

\begin{abstract}
A B S T R A C T
Using a unique micro-level data set over the period 1998-2005 on Chinese firms, this paper presents empirical findings on the presence of credit constraints. Our findings are threefold. Firstly, private Chinese firms are credit constrained while state-owned firms and foreign-owned firms in China are not; Secondly, the geographical and sectoral presence of foreign capital alleviates credit constraints faced by private Chinese firms. Thirdly, geographical and sectoral presence of state firms aggravates financial constraints for private Chinese firms ("crowding out").
\end{abstract} (c) 2010 Published by Elsevier Inc.

\section{Introduction}

There exits considerable evidence that financial constraints are an impediment to investment and growth of firms (Stein, 2003; Hubbard, 1998). This is even more important in developing countries, where the access to financial markets is a crucial determinant for the growth and survival of firms. Financial constraints can arise from various kinds of sources. The literature identifies informational asymmetries and agency problems as the most important factors influencing the allocation process of financial resources to firms. ${ }^{1}$

Capital market imperfections are believed to be very present in China. By law, the largest Chinese banks, which were predominantly state banks, were until 1998 instructed not to lend to private firms. This was embedded in the political notion that private firms do not rank high in terms of political status. This "political pecking order" in the allocation of credit where private Chinese firms were disadvantaged should in principle have been alleviated since 1998. But casual evidence suggests that credit constraints for private firms are still present which may impede the growth of the Chinese economy (Huang, 2003). ${ }^{2}$

Several macro studies have emphasized the prevalence of capital market imperfections allocation in China ${ }^{3}$, with only a few studies at the micro-level. ${ }^{4}$ The macro-level studies analyze the links between finance and growth in China and characterize it as a counterexample to the positive relationship generally found between finance and growth in the literature. Indeed, in spite of financial system flaws, China has one of the fastest growing economies.

\footnotetext{
* Corresponding author. Tel.: + 32104743 16; fax: + 3210474301.

E-mail addresses: sandra.poncet@univ-paris1.fr (S. Poncet), steingre@bu.edu (W. Steingress), hylke.vandenbussche@uclouvain.be (H. Vandenbussche).

1 See Stein (2003) and Hubbard (1998) for a review.

2 Capital market imperfections may respond with a lag to institutional and legal changes.

3 Allen, Qian, and Qian (2005), Guariglia and Poncet (2008).

${ }^{4}$ Héricourt and Poncet (2008), Guariglia, Liu, and Song (2008).
} 
The analysis in this paper is a micro-level study that extends the literature in several dimensions. First, it offers an explanation for the conundrum of firm growth in China despite evidence of credit constraints. We look at the presence of foreign capital and how it can mitigate the financial constraints experienced by Chinese private firms. Our evidence suggests that foreign firms in China are not credit constrained (Naughton, 2007). While we cannot formally test the channels of credit, foreign firms may be less dependent on the local financial system in China since they can rely on outside sources to finance their growth. Either they can continue to have access to capital markets abroad or rely on intra-firm financial transfers provided by affiliated firms abroad. Our results suggest that the stronger the presence of foreign capital in a sector or region, the lower the financial constraints faced by Chinese private firms operating in the same region and sector. This indicates that the presence of foreign capital somehow allows Chinese private firms to bypass both the financial and legal obstacles that they face at home. This paper does not argue that the presence of foreign firms can affect the lending policies of local banks. ${ }^{5}$ Instead, its findings are in line with the hypothesis put forward by Huang (2003) that FDI mitigates the credit constraints faced by Chinese private firms due to inefficiencies in the banking sector for which only macro-level evidence existed so far (Guariglia, Liu, \& Song, 2008). Our results for China differ from earlier findings in the literature. For instance Harrison and McMillan (2003) for the Ivory Coast find that the presence of foreign firms crowds local firms out of domestic capital markets. Our results suggest that for China this is not the case. For China we find that the geographical presence of foreign firms alleviates credit constraints of private Chinese firms. While our data do not permit us to identify the channel of this spillover, one possibility is that foreign firms extend more trade credit to local Chinese firms. Indeed when we introduce the amount of trade credit of Chinese firms into the analysis we find that private firms with access to trade credit are less constrained which appears consistent with that explanation.

In contrast, the presence of state firms in the local economy does appear to have "crowding out" effects since we find that state firms' presence aggravates the financial constraints of private Chinese firms.

From a methodological point of view we follow Harrison, Love, and McMillan (2004). We introduce external financing costs in the investment Euler equation to evaluate the magnitude of financial constraints in China. Sensitivity of investment to cash flow is associated with financial constraints. In perfect capital markets and in the absence of credit constraints, cash flow should not affect future investment. If results show otherwise this can be interpreted as an indication that capital markets are not perfect and that credit constraints exist.

Our work is related to the existing literature on capital market imperfections and firm investment in transition and developing economies (see Konings, Rizov, \& Vandenbussche, 2003; Lizal \& Svejnar, 2002; Harrison \& McMillan, 2003).

In the first part of the paper, we analyze whether different types of firm ownership face a different degree of financial constraints. In the second part, we investigate how Foreign Direct Investment (FDI) and the presence of state firms interact with the credit constraints that appear to exist for Chinese private firms. More precisely we test whether the geographical and sectoral presence of foreign investment in China plays an important role in modulating private firms' credit constraints and similarly for the geographical and sectoral presence of state-owned firms.

Our analysis is carried out on Chinese firm-level data originating from the data set ORIANA (2009) ${ }^{6}$ covering more than 20,000 Chinese firms over the period 1998-2005. We should point out that our empirical strategy should not be interpreted as a direct test of the political pecking order theory. ${ }^{7}$ Our findings merely confirm that private firms face the highest degree of financial constraints, whereas state-owned enterprises ( $\mathrm{SOE}$ ) and foreign firms do not experience any financial constraints which are consistent with the predictions from the political pecking order hypothesis. We find that the sensitivity of private firms' investment to cash flow softens in a context of abundant foreign investment. This suggests that the presence of foreign firms in China improve the functioning of capital markets for private Chinese firms, which is good for growth. In contrast, credit constraints for private Chinese firms are reinforced when the presence of state-owned firms is strong. These results obtained over the period 1998-2005 suggest that the ongoing restructuring of SOE may help to circumvent credit constraints and can boost the investment and growth of private firms.

At this point we should point out some of the limitations of our analysis. In our empirical strategy we use firm-level cash flow as a regressor in an investment equation. But cash flow is likely to be an endogenous variable. To account for this we follow the literature in using an IV approach using lagged values of the endogenous variable. Lagged values are however a-theoretical instruments and not ideal but due to the lack of a good alternative set of instruments, most other studies have used lagged values. An additional difficulty we face is that the panel dimension of our data is relatively short. This limits the number of lags we can use as instruments in the IV identification strategy that we pursue. These limitations have to be kept in mind in considering our findings.

The remainder of this paper is organized as follows. Section 2 provides a theoretical justification for our measure of financing constraints. Section 3 describes the data. Section 4 presents estimation results of the baseline model which tests whether firms face different credit constraints depending on their capital ownership (private, foreign or State-owned status). Section 5 allows for provincial and industry heterogeneity and tests whether direct foreign investment and state presence affects the credit constraints faced by private firms. Section 6 concludes.

\section{Theoretical background}

The central idea of the literature on financing constraints is that investment should not be determined by a firm's net worth or internal funds but only by the firm's expected future profitability. The seminal work of Modigliani and Miller (1958) indeed

\footnotetext{
5 This paper focuses on the role of FDI as an alternative source of funding to loans from the banking system. It does not make any attempt to study the various ways by which the presence of foreign firms can affect the lending policies of local banks.

6 This database contains detailed financial information on contact information, activities, ownership and financing.

7 To make definite statements on 'the political pecking order' one would need to compare the actual financing decisions of state-owned, foreign, and private firms, which this paper does not do.
} 
suggests that in perfect capital and credit markets the financing decision of a firm is irrelevant for its investment behavior and viceversa. However, in the presence of capital market imperfections, financing constraints will be reflected in firms' investment decisions. Empirically, financing constraints could be identified via the sensitivity of investment to internal funds. A number of recent papers have called into question the validity of using investment-cash flow correlations as proxies for financing constraints (Allen, Qian, \& Qian, 2005, 1997; Alti, 2003; Gomes, 2001). However, many authors still support the use of investment-cash flow sensitivity as an indicator of credit constraints (Allayannis \& Muzomdar, 2004; Fazzari et al., 2000). While it is true that no theoretical consensus has been reached and that the relationship between investment and cash flow sensitivities continues to be an important empirical question, numerous recent results and survey evidence support the intuition that investment-cash flow sensitivities are indeed a reflection of the extent of financing constraints (Beck, Demirguc-Kunt, \& Maksimovic, 2005; Love, 2003). As explained by Harrison et al. (2004), most papers which question this methodology relate more directly to the Q-model of investment rather than the Euler equation model (although some of the criticisms apply to both models).

For this purpose we estimate a version of the Euler equation, combining insights from Whited (1992), Bond and Meghir (1994) and Love (2003). The Euler equation characterizes a firm's optimal investment path and relates it to marginal adjustment costs in adjacent periods. A credit constrained firm behaves as if it had a higher discount rate for a given level of today's adjustment costs. Ceteris paribus, constrained firms will then substitute investment tomorrow for investment today. We closely follow Harrison and Love et al. (2004) and define the value of the firm as $V_{t}$ :

$$
V_{t}\left(K_{t}, \xi_{t}\right)=\max _{I_{t}+s_{s=0}^{\infty}} D_{t}+E_{t}\left(\sum_{s=1}^{\infty} \beta_{t+s} D_{t+s}\right)
$$

where

$$
\begin{aligned}
& D_{t}=\Pi\left(K_{t}, \xi_{t}\right)-C\left(K_{t}, I_{t}\right)-I_{t} \\
& K_{t+1}=(1-\delta) K_{t}+I_{t} \\
& D_{t} \geq 0
\end{aligned}
$$

where the value of a firm in Eq. (1) is defined as the discounted stream of future dividends paid out to shareholders, where $\beta_{t+s}$ is the discount factor from the period $t$ to period $t+\mathrm{s}$ and $D_{t}$ is the dividend. Eq. (2) shows that the dividend that is paid out to shareholders in each period equals profits $\Pi\left(K_{t}, \xi_{t}\right)$ minus the adjustment cost of new investment $C\left(K_{t}, I_{t}\right)$ minus investment expenditure $I_{t}$. The restricted profit function is denoted by $\Pi\left(K_{t}, \xi_{t}\right)$, where $\xi_{t}$ is a productivity shock specific for each firm. The costs of adjusting the stock of capital $C\left(K_{t}, I_{t}\right)$ correspond to disruption costs, costly learning, delivery lags and time to install new or replacement capital. It is assumed to result in a loss of a portion of the investment. In the capital accumulation constraint (Eq. (3)), $K_{t}$ is the capital stock at the beginning of the period, $I_{t}$ is the investment expenditure and $\delta$ is the depreciation rate. Credit constraints are modeled as a non-negative dividend constraint (Eq. (4)). Let the multiplier on this constraint be denoted by $\lambda_{t}$. This multiplier is interpreted as a shadow cost associated with raising new equity, which implies that external financing is costly.

Following Harrison and Love et al. (2004), we obtain the Q-model of investment as a first-order condition from the above model. After combining it with the envelope condition and rearranging it we get the Euler equation:

$$
1+\frac{\partial C\left(I_{t}, K_{t}\right)}{\partial I_{t}}=\beta_{t} E_{t}\left[\Omega_{t}\left[\frac{\partial \Pi_{t+1}}{\partial K_{t}+1}+(1-\delta)\left(1+\frac{\partial C\left(I_{t+1}, K_{t+1}\right)}{\partial I_{t}+1}\right)\right]\right]
$$

where

$$
\Omega_{t}=\frac{1+\lambda_{t+1}}{1+\lambda_{t}}
$$

In Eq. (5), $\frac{\partial \Pi_{t+1}}{\partial K_{t+1}}$ is the marginal profit of capital, i.e. the contribution of an extra unit of capital to the firm's profits. In the Euler equation the factor $\Omega_{t}$ is the relative shadow cost of external finance in periods $t$ and $t+1$ and serves as a proxy for the degree of financing constraints. If $\lambda_{t+1}=\lambda_{t}=0$ then $\Omega_{t}=1$, we are in a perfect capital market and the external costs of financing is $1{ }^{8}$ If the shadow cost of external funds is higher in period $t$ than in period $t+1$, so $\Omega<1$, then current funds are relatively more expensive today than tomorrow. In this case we say that the firm is financially constrained. If the shadow cost of current funds $\lambda_{t}$ is less expensive today than tomorrow $(\Omega>1)$, then the firm will invest today. ${ }^{9}$ Firms do not face financial constraints if the shadow cost of investment $\lambda_{t+1}=\lambda_{t}=0$ for all time periods.

It is important to stress that there is no implicit assumption on the source of external funds. The model is consistent with the Chinese specificity that private domestic firms rely principally on informal sources of finance that are based on reputation and relationships such as loans from family and friends and from private (unofficial) credit agencies (Allen et al., 2005). ${ }^{10}$ Common to the literature is that

\footnotetext{
${ }^{8}$ Another possibility would be if $\lambda_{t+1}=\lambda_{t} \neq 0$, then current firms are constrained by the same factor in period $t$ and $t+1$. Since the shadow cost depends also on the productivity shock $\xi_{t}$ it is unlikely that $\lambda_{t+1}=\lambda_{t}$ in all periods, although for some firms in some periods this is possible. Still we argue as in Love (2003) that in estimating ownership-wide constraints given firm specific investment opportunities such a situation is unlikely to occur.

${ }_{9}$ We thank an anonymous referee for raising this issue.

${ }^{10}$ To make definite statements on the 'political pecking order' one would need to compare the actual financing decisions of state-owned, foreign, and private firms, which this paper does not do.
} 
financial constraints are measured by the sensitivity of investment with respect to internally generated funds. The sensitivity of investment to internal generated funds such as cash flow, is a well reported fact in the literature (Carpenter \& Petersen, 2002; Fazzari, Hubbard, \& Petersen, 1988a,b). We assume that firms make their decision for period $t$ investment at the beginning of the year. Therefore the decisive value of cash flow is in period $t-1$ since the firm gauges its previous cash flow to determine the current investment decision.

In this paper we focus on institutional imperfections in Chinese credit markets and the hypothesis that access to credit is based on ownership i.e. the political pecking order that leads to a gap between the costs of internal versus external financing. To test for different ownership effects, we split our sample between private, state-owned and foreign companies.

To derive the estimation equation, we assume constant returns to scale production function with quadratic adjustment costs of investment. Similar to the previous literature, Harrison and Love et al. (2004) and Love (2003), we include the lagged investment to capital ratio $\left(\frac{I_{i, t-1}}{K_{i, t-1}}\right)$ in the cost function to allow for a correlation between the previous and current investment decisions. We expect the labor to capital ratio $(L / K)$ to proxy for the marginal product of profits with respect to capital as it is conceivable that higher investment leads to a higher capital to labor ratio. Moreover, if we assume rational expectations, we can replace the future realizations of the variables with the real terms together with a measurement error $\varepsilon_{i, t}$. Firm specific investment opportunities are approximated by the change in turnover over capital $\left(\frac{\Delta T U_{i, t}}{K_{i, t}}\right)$. Our main variable of interest is the cash flow ratio Foreign_Firm $\mathrm{i}_{\mathrm{i}, p k, t}$ whose sign and significance is our measure of credit constraints. Given our assumptions, the empirical equation that we seek to estimate has the following standard specification:

$$
\frac{I}{K t}_{i, t}=\beta_{1}{\frac{I_{i t-1}}{K}}_{i, t-1}+\beta_{2}{\frac{L_{i t}}{K}}_{i, t}+\beta_{3}{\frac{\Delta T U_{i t}}{K}}_{i, t}+\beta_{4}{\frac{C F_{i t-1}}{K}}_{i, t-1}+\mu_{k, t}+\varepsilon_{i, t}
$$

In the above equation, $I$ denotes gross investment in fixed assets, ${ }^{11} L$ is the number of employees, $K$ is the level of the real capital stock (proxied by total assets), $\Delta \mathrm{TU}$ corresponds to the change in turnover and CF stands for cash flow. The subscripts $i, k$ and $t$ denote the firm, industry and time period, respectively; and $\mu_{k, t}$ captures the sector-time specific effects, $\varepsilon_{i, t}$ is the error term. We expect that in Eq. (7) current investment is negatively related to past investment and to the employment over assets ratio. We further expect current investment to be positively related to favorable business prospects captured by the current change in turnover over assets ratio. As we discussed above, we measure financing constraints by the sensitivity of investment to cash flow. We argue that the larger this sensitivity, the more constrained the firm is since it has to rely on its internal funds to finance its investment. If the political pecking order holds, it would show up in the empirics as an insignificant coefficient on the cash flow indicator $\left(\beta_{4}\right)$ when the sample is restricted to state-owned or to foreign firms, but a positive and significant coefficient when private firms are considered since they supposedly have least access to external funds. While our empirical strategy should not be interpreted as a direct test, our findings do appear to be in line with what the political pecking order predicts.

To study the contingency of credit constraints for Chinese private firms, we include variables measuring the presence of foreign investment and state firms by province and by province/sector and interact those with our proxies for credit constraints.

\section{Data}

The data that we use are firm-level data originating from the Oriana data set. ${ }^{12}$ This database contains detailed financial information on contact information, activities, and ownership of more than 20,000 Chinese firms in the time period of 1998 to 2005. Our data were collected by local governments based on the Accounting Standards for Business Enterprises (ASBE) system promulgated by the Ministry of Finance in 1992. We distinguish among different types of legal ownership: state and collective owned enterprises, foreign invested enterprises, and private Chinese companies. A firm is classified by Oriana as a state-owned enterprise (SOEs) if the ownership share of the state (no matter whether direct or indirect) is more than $25 \%{ }^{13}$

The companies included in the database are either publicly listed or satisfy at least one of the following size criteria: minimum number of employees is 150 , or annual turnover and total assets are at least 10 million and 20 million USD, respectively. For the purpose of this study, we retrieved detailed information on 23,613 firms in the People's Republic of China. Although no data exist on the extent of informal sources of financing and the types of financing (actions, bonds, loans...), one should note that our methodology of eliciting credit constraints through the correlation of debt and cash flows with investment would still be relevant.

As far as data cleaning is concerned, firm-level data from transition and developing economies often suffer from accounting deficiencies, and usually contain missing values and outlier observations that may bias the estimated coefficients. After eliminating the observations that were based on irregular reports or unreasonable data values in the levels of variables (such as negative values for material costs), we have a total of 22,311 observations from 14,967 firms. ${ }^{14}$

\footnotetext{
11 It is defined as the change in the tangible fixed assets of firm $i$ between time $t-1$ and time $t$ plus the firm specific depreciation rate of capital. Almeida and Campello (2006) argue that excluding intangible assets (patents, copyrights, trademarks, etc.) from the definition of investment reduces measurement errors of investment.

12 Oriana dataset is made available by Bureau van Dijk (ORIANA, 2009). It is constructed from Huaxia credit.

13 See Huyghebaert, Quan, and Sun (2006).

14 As far as the data coverage of our sample is concerned, a comparison of our data with the China Economic Census Yearbook 2004 reveals that the Oriana data covers 52\% of total manufacturing sales of medium-size and large-size enterprises in China (Abraham and Konings et al., 2007). A closer look at the regional and sectoral composition of Oriana reveals that it is quite similar to the Census: $87 \%$ of the firms in Oriana are operating in the manufacturing sector compared to $93 \%$ in the Census. In the Oriana data set, as pointed out by Abraham and Konings et al. (2007), both the state sector and foreign firms are slightly over-represented: $16 \%$ of the firms in Oriana is owned by the state, versus $13 \%$ in the Census, and $36 \%$ (Oriana) versus 20\% (Census) of firms are foreign-owned (including Hong Kong, Macau, and Taiwan). It is however hard to determine to which extent these differences could affect the reliability of our results.
} 
Table 1

Summary statistics.

\begin{tabular}{|c|c|c|c|c|}
\hline Variable & Mean (1) & Standard deviation (2) & Minimum (3) & Maximum (4) \\
\hline \multicolumn{5}{|l|}{ Private firms (1):5669 } \\
\hline Investment over capital & 0.086 & 0.150 & -0.487 & 1.605 \\
\hline Lagged investment over capital & 0.103 & 0.162 & -0.483 & 1.600 \\
\hline Change in turnover over capital & 0.290 & 1.061 & -32.699 & 21.975 \\
\hline Cash flow over capital & 0.069 & 0.105 & -1.460 & 2.503 \\
\hline Employment over capital & 0.006 & 0.013 & 0.000 & 0.454 \\
\hline Total employment & 1829 & 3534 & 5 & 88,547 \\
\hline Total assets & $1,273,416$ & $3,746,566$ & 873 & $145,000,000$ \\
\hline \multicolumn{5}{|l|}{ State-owned enterprises (2): 2357} \\
\hline Investment over capital & 0.075 & 0.144 & -0.442 & 1.159 \\
\hline Lagged investment over capital & 0.080 & 0.134 & -0.442 & 1.217 \\
\hline Change in turnover over capital & 0.158 & 0.411 & -5.784 & 6.767 \\
\hline Cash flow over capital & 0.051 & 0.076 & -0.357 & 0.938 \\
\hline Employment over capital & 0.004 & 0.005 & 0.000 & 0.082 \\
\hline Total employment & 4623 & 21,989 & 1 & 439,220 \\
\hline Total assets & $3,461,728$ & $27,800,000$ & 5571 & $778,000,000$ \\
\hline \multicolumn{5}{|c|}{ Collective owned enterprises (3): 1640} \\
\hline Investment over capital & 0.076 & 0.151 & -0.540 & 1.679 \\
\hline Lagged investment over capital & 0.091 & 0.157 & -0.369 & 1.388 \\
\hline Change in turnover over capital & 0.395 & 1.285 & -13.295 & 23.060 \\
\hline Cash flow over capital & 0.106 & 0.188 & -1.435 & 4.602 \\
\hline Employment over capital & 0.008 & 0.020 & 0.000 & 0.379 \\
\hline Total employment & 1624 & 3918 & 6 & 99,147 \\
\hline Total assets & 749,479 & $2,203,650$ & 2396 & $42,400,000$ \\
\hline \multicolumn{5}{|c|}{ Foreign invested enterprises (4): 5301} \\
\hline Investment over capital & 0.063 & 0.142 & -0.834 & 1.642 \\
\hline Lagged investment over capital & 0.076 & 0.147 & -0.670 & 1.624 \\
\hline Change in turnover over capital & 0.264 & 0.952 & -18.584 & 19.566 \\
\hline Cash flow over capital & 0.109 & 0.175 & -1.385 & 8.458 \\
\hline Employment over capital & 0.009 & 0.020 & 0.000 & 0.441 \\
\hline Total employment & 1367 & 3455 & 10 & 140,000 \\
\hline Total assets & 699,955 & $2,075,153$ & 1102 & $38,900,000$ \\
\hline
\end{tabular}

(1) Private firms in our sample refer to $100 \%$ domestically owned profit-making economic organizations in accordance with the Company Law of the People's Republic of China. The legal form of private Chinese firms can be private Limited Liabilities, Private Partnership, Private Share Holding or Private Sole Investment. (2) State-owned enterprises (SOE) refers to $100 \%$ domestically owned firms where the state (no matter whether direct or indirect) has at least $25 \%$ of ownership stake. These arrangements can be either be fully State-owned or Jointly State-owned with another party.

(3) Collective owned enterprises (COE) refers to $100 \%$ domestically owned corporation where the means of production and property belonging to laboring masses and are managed by local governments.

(4) Foreign invested enterprise (FIE) groups firms with more than $25 \%$ of registered capital by a foreign party.

In our empirical estimations we pool SOEs with urban and rural collectively owned enterprises (COEs). The collective owned enterprise is an independent economic organization and legal corporation with means of production and property belonging to laboring masses and managed by local government. COEs should rank quite high in the political pecking order and are expected to receive better access to external funds than private firms which is why we consider them together with SOEs in the analysis. ${ }^{15}$

Private firms in our sample refer to profit-making economic organizations, which can either be sole proprietorships, partnerships, limited liability companies, or shareholding cooperatives. ${ }^{16}$ Foreign firms or foreign invested enterprises refer to any enterprise domiciled in mainland China that has at least $25 \%$ of the total equity stake of the firm owned by a foreign entity.

The construction of the sample used in our regressions is essentially driven by the dynamic nature of our model (Eq. (7)). Our sample is restricted to companies that report in at least two consecutive years. Furthermore, we delete the upper and the lower one percentile of the distribution of the dependent variable to get rid of outliers. We verify that our results are robust to the deleting of the upper and the lower five percentile of the distribution. Although this procedure excludes several hundred observations, it does not significantly alter the main results. ${ }^{17}$

Table 1 reports the summary statistics of the firms used in our empirical work according to their ownership structure. The values in column (1) represent the statistical means together with the standard errors in (2), minimum (3) and maximum values

\footnotetext{
${ }^{15}$ Following an anonymous referee's suggestion, we verified that findings of no credit constraints for state-owned firms were robust to the exclusion of the collective firms from the SOE category. Results are available upon request.

16 Another form of individual businesses, known as Getihu, are not included in the data set since they are by law not allowed to have more than eight employees and are thus too small to be included.

17 We thank an anonymous referee for this suggestion. Results of this alternative outlier correction procedure are available upon request.
} 
Table 2

OLS, IV technique and firm fixed effects to test for credit constraints across ownership types.

\begin{tabular}{|c|c|c|c|c|c|c|c|c|c|}
\hline \multirow{3}{*}{$\begin{array}{l}\text { Dependent variable: } \\
\text { investment over lagged } \\
\text { total assets }\end{array}$} & (1) & (2) & (3) & (4) & (5) & (6) & (7) & (8) & (9) \\
\hline & Private & SOE & Foreign & Private & SOE & Foreign & Private & SOE & Foreign \\
\hline & OLS & OLS & OLS & IV & IV & IV & $\mathrm{FE}$ & FE & $\mathrm{FE}$ \\
\hline $\begin{array}{l}\text { Lag dependent (investment } \\
\text { divided by lagged } \\
\text { total assets) } i, t-1\end{array}$ & $\begin{array}{l}0.095^{*} \\
(0.014)\end{array}$ & $\begin{array}{l}-0.009^{*} \\
(0.002)\end{array}$ & $\begin{array}{l}0.100^{*} \\
(0.019)\end{array}$ & $\begin{array}{l}0.125^{*} \\
(0.025)\end{array}$ & $\begin{array}{l}-0.048 \\
(0.039)\end{array}$ & $\begin{array}{l}0.114^{*} \\
(0.020)\end{array}$ & $\begin{array}{l}-0.365^{*} \\
(0.016)\end{array}$ & $\begin{array}{l}-0.623^{*} \\
(0.024)\end{array}$ & $\begin{array}{l}-0.528^{*} \\
(0.018)\end{array}$ \\
\hline $\begin{array}{l}\text { Change in turnover over } \\
\text { assets } i, t\end{array}$ & $\begin{array}{l}0.021^{*} \\
(0.004)\end{array}$ & $\begin{array}{l}0.108^{* *} \\
(0.047)\end{array}$ & $\begin{array}{l}0.012^{*} \\
(0.003)\end{array}$ & $\begin{array}{l}0.027^{*} \\
(0.007)\end{array}$ & $\begin{array}{l}0.070^{*} \\
(0.025)\end{array}$ & $\begin{array}{l}0.013^{*} \\
(0.003)\end{array}$ & $\begin{array}{l}0.038^{*} \\
(0.003)\end{array}$ & $\begin{array}{l}0.062^{*} \\
(0.005)\end{array}$ & $\begin{array}{l}0.010^{*} \\
(0.003)\end{array}$ \\
\hline Employment over assets $i, t$ & $\begin{array}{l}-0.357 \\
(0.251)\end{array}$ & $\begin{array}{l}-1.489^{* *} \\
(0.617)\end{array}$ & $\begin{array}{l}-0.247^{*} \\
(0.094)\end{array}$ & $\begin{array}{l}-3.219^{*} \\
(1.002)\end{array}$ & $\begin{array}{l}-7.320^{* *} \\
(3.342)\end{array}$ & $\begin{array}{l}-0.598 \\
(0.543)\end{array}$ & $\begin{array}{l}-6.906^{*} \\
(1.423)\end{array}$ & $\begin{array}{l}-14.646^{*} \\
(2.793)\end{array}$ & $\begin{array}{l}-5.827^{*} \\
(1.779)\end{array}$ \\
\hline Cash flow over assets $i, t-1$ & $\begin{array}{l}0.121^{*} \\
(0.037)\end{array}$ & $\begin{array}{l}-0.088 \\
(0.159)\end{array}$ & $\begin{array}{l}0.028 \\
(0.023)\end{array}$ & $\begin{array}{l}0.109^{* * *} \\
(0.058)\end{array}$ & $\begin{array}{l}0.076 \\
(0.203)\end{array}$ & $\begin{array}{l}0.013 \\
(0.019)\end{array}$ & $\begin{array}{l}0.134^{*} \\
(0.033)\end{array}$ & $\begin{array}{l}0.090 \\
(0.087)\end{array}$ & $\begin{array}{l}-0.019 \\
(0.033)\end{array}$ \\
\hline $\begin{array}{l}\text { Cash flow squared over total } \\
\text { assets } i, t-1\end{array}$ & & & & & & & $\begin{array}{l}-0.149^{*} \\
(0.025)\end{array}$ & $\begin{array}{l}-0.062^{*} \\
(0.018)\end{array}$ & $\begin{array}{l}0.016^{* *} \\
(0.007)\end{array}$ \\
\hline Sector-year fixed effects & Yes & Yes & Yes & Yes & Yes & Yes & Yes & Yes & Yes \\
\hline Firm fixed effects & No & No & No & No & No & No & Yes & Yes & Yes \\
\hline Observations number & 9229 & 5766 & 7316 & 4152 & 1607 & 1994 & 9229 & 5766 & 7316 \\
\hline$R$-squared & 0.074 & 0.191 & 0.026 & 0.110 & 0.124 & 0.027 & 0.195 & 0.386 & 0.314 \\
\hline $\begin{array}{l}\text { Cragg-Donald F statistic } \\
\text { (weak identification test) }\end{array}$ & & & & 727 & 210 & 1605 & & & \\
\hline $\begin{array}{l}\text { Sargan statistic } \\
\text { (overidentification test of } \\
\text { all instruments): Chi-sq(1) } \\
P \text {-val }\end{array}$ & & & & $\begin{array}{l}0.084 \\
(0.776)\end{array}$ & $\begin{array}{l}5.956^{* *} \\
(0.0147)\end{array}$ & $\begin{array}{l}3.077^{* * *} \\
(0.0794)\end{array}$ & & & \\
\hline
\end{tabular}

Standard errors in parentheses.

In columns 4 to 6 , cash flow over assets $i, t-1$ is instrumented with cash flow over assets $i, t-2$ and cash flow over assets $i, t-3$.

* Significant at $1 \%$.

** Significant at $5 \%$.

**** Significant at $10 \%$.

(4) over the sample period. In terms of ownership representation, $38 \%$ of the total number of firms in our data is private firms, while $35 \%$ are foreign firms. State-owned firms and collective firms represent $27 \%$ of our sample.

Overall, the summary statistics in Table 1 show amongst others that private Chinese firms are smaller than SOEs, generate more internal funds and are typically more efficient in investing their capital.

\section{Investment equation estimates}

Results for our baseline specification (Eq. (7)) are reported in Table 2. They are shown for different types of ownership i.e. domestic private firms (columns 1, 4 and 7), SOE firms (columns 2, 5 and 8) and foreign firms (columns 3,6 and 9). All regressions include sector level specific time dummies defined at the two-digit sector level (26 sectors) to control for shifts in investment demand or expectations due to changes in industry-level conditions (for example, industry-wide technology changes, industry demand shocks, or the entry of new firms). Our main variable of interest is the coefficient on the cash flow. When investment significantly depends on a firm's internally generated cash flow, this can be regarded as an indication that the firm is credit constrained. We estimate successively our model with OLS, IV and firm fixed effects to check the robustness of our results. We start by reporting OLS results in columns 1 to 3 . As conjectured, we find that private firms in China significantly rely on their cash flow to finance their investments, which is evidence of credit constraints, while SOEs and foreign firms do not. The results are robust to the inclusion of sector-time effects or time effects only. However, the OLS estimates may be biased due to the endogeneity of the cash flow, our proxy for internal finance. In columns 4 to 6 we apply an IV technique to address this where we use the cash flow over assets in periods $t-2$ and $t-3$ as instruments. ${ }^{18}$ The results go through be it with a weaker significance of the positive coefficient on the private firms, suggesting that the endogeneity of the cash flow is not too serious an issue. We systematically check the validity of our instruments with Sargan's J-test of overidentifying restrictions. Insignificant test statistics indicate that the orthogonality of the instruments and the error terms cannot be rejected, and thus that our choice of instruments is appropriate. ${ }^{19}$ In the case of private firms (column 4), the overidentifying restrictions are accepted. By constrast the Sargan test rejects the validity of our instruments for state and foreign firms, a problem encountered also in previous work emphasizing the weakness of IV instruments in this kind of estimations (Aghion, Askenazy, \& Berman, 2008). We also report the cluster-robust F-stat form of the Cragg-Donald statistic; this statistic has been suggested by Stock and Yogo (2002) as a global test for the presence of weak instruments (i.e., it tests the null hypothesis that a given group of instruments is weak against the alternative that it is strong). The

\footnotetext{
${ }^{18}$ Javorcik and Spatareanu (2008) in addition to the cash flow also instrument several other independent variables using a GMM approach. However, due to the short time dimension of our panel we cannot pursue the same approach.

${ }^{19}$ Under the joint null hypothesis that instruments are valid instruments and that the excluded instruments are correctly excluded from the estimated equation, the test statistic is distributed as $\chi^{2}$ in the number of other identifying restrictions. Significance is judged at the $10 \%$ level.
} 
Table 3

Robustness check: alternative proxy for credit constrains across ownership types.

\begin{tabular}{|c|c|c|c|c|c|c|}
\hline \multirow[b]{3}{*}{ Dependent variable: investment over lagged total assets } & (1) & $(2)$ & (3) & (4) & $(5)$ & $(6)$ \\
\hline & $\mathrm{FE}$ & $\mathrm{FE}$ & $\mathrm{FE}$ & $\mathrm{FE}$ & $\mathrm{FE}$ & $\mathrm{FE}$ \\
\hline & Private & SOE & Foreign & Private & SOE & Foreign \\
\hline $\begin{array}{l}\text { Lag dependent (investment divided by lagged total assets) } \\
i, t-1\end{array}$ & $\begin{array}{l}-0.370^{* * *} \\
(0.015)\end{array}$ & $\begin{array}{l}-0.630^{* * *} \\
(0.027)\end{array}$ & $\begin{array}{l}-0.545^{* * *} \\
(0.017)\end{array}$ & $\begin{array}{l}-0.366^{* * *} \\
(0.016)\end{array}$ & $\begin{array}{l}-0.624^{* * *} \\
(0.024)\end{array}$ & $\begin{array}{l}-0.530^{* * *} \\
(0.018)\end{array}$ \\
\hline Change in turnover over assets $i, t$ & $\begin{array}{l}0.033^{* * *} \\
(0.002)\end{array}$ & $\begin{array}{l}0.051^{* * *} \\
(0.005)\end{array}$ & $\begin{array}{l}0.012^{* * *} \\
(0.003)\end{array}$ & $\begin{array}{l}0.039^{* * *} \\
(0.003)\end{array}$ & $0.062^{* * *}$ & $\begin{array}{l}0.010^{* * *} \\
(0.003)\end{array}$ \\
\hline Employment over assets $i, t$ & $\begin{array}{l}-5.970 \\
(1.393)\end{array}$ & $\begin{array}{l}-31.137^{* * *} \\
(0.877)\end{array}$ & $\begin{array}{l}-3.636^{* * *} \\
(1.363)\end{array}$ & $\begin{array}{l}-6.938^{* * *} \\
(1.422)\end{array}$ & $\begin{array}{l}-14.663^{* * *} \\
(2.795)\end{array}$ & $\begin{array}{l}-5.898^{* * *} \\
(1.780)\end{array}$ \\
\hline Total liabilities over total assets $i, t-1$ & $\begin{array}{l}-0.042^{* * *} \\
(0.010)\end{array}$ & $\begin{array}{l}-0.051 \\
(0.032)\end{array}$ & $\begin{array}{l}0.013 \\
(0.012)\end{array}$ & $\begin{array}{l}-0.032^{* * *} \\
(0.011)\end{array}$ & $\begin{array}{l}-0.007 \\
(0.030)\end{array}$ & $\begin{array}{l}0.017 \\
(0.013)\end{array}$ \\
\hline Cash flow over assets $i, t-1$ & & & & $\begin{array}{l}0.110^{* * *} \\
(0.033)\end{array}$ & $\begin{array}{l}0.089 \\
(0.087)\end{array}$ & $\begin{array}{l}-0.008 \\
(0.034)\end{array}$ \\
\hline Cash flow squared over assets $i, t-1$ & & & & $\begin{array}{l}-0.140^{* * *} \\
(0.025)\end{array}$ & $\begin{array}{l}-0.062^{* * *} \\
(0.018)\end{array}$ & $\begin{array}{l}0.016^{\text {** }} \\
(0.007)\end{array}$ \\
\hline Firm fixed effects & Yes & Yes & Yes & Yes & Yes & Yes \\
\hline Sector-year fixed effects & Yes & Yes & Yes & Yes & Yes & Yes \\
\hline$R$-squared & 0.201 & 0.581 & 0.341 & 0.198 & 0.386 & 0.315 \\
\hline Observations number & 9481 & 5996 & 7527 & 9229 & 5766 & 7316 \\
\hline Number of firms & 5829 & 4264 & 5407 & 5669 & 4138 & 5301 \\
\hline
\end{tabular}

Standard errors in parentheses.

*** Significant at $5 \%$.

** Significant at $10 \%$.

test rejects if the computed statistic exceeds the critical value. The results we obtain for weak identification tests are overall quite satisfactory. Our instruments pass comfortably the Cragg-Donald test in all cases since our first stage F-statistics are consistently above 10, in line with the Staiger-Stock (1997) "rule of thumb".

Another drawback of the OLS results presented in the first three columns of Table 2 is that some firm-level factors such as the user cost of capital are omitted..$^{20}$ In columns 7 to 9 , we include firm fixed effects to control for all unobserved time-invariant variables as in the related work of Bond and Meghir (1994) and Harrison and McMillan (2003). It also controls for the possibility of a correlation between a time-invariant component of the error term and the regressors which would make the pooled OLS estimation inconsistent. ${ }^{21}$ In addition we also include a squared cash flow term to allow for non-linearities in credit constraints. The motivation to include a squared cash flow term is to allow for non-linearity in the investment sensitivity to cash flows. ${ }^{22} \mathrm{As}$ uncovered by Hansen and Tarp (2001) in the context of the conditional impact of aid on growth it is crucial to control for nonlinearity (such as decreasing returns) before investigating potential conditionality of the impact. ${ }^{23}$ The significance of the interactive term in most specifications attests to the pertinence of the quadratic specification compared to the linear specification.

The results with the firm fixed effects in the last three columns of Table 2 show that the coefficient on cash flow again is positive (and highly significant) for private firms. The negative and significant sign on the squared term suggests that a higher cash flow moderates the extent of the credit constraint for private Chinese firms. Conversely, public companies' and foreign companies' investments are not positively affected by cash flow. The specification in column 7 for Chinese private firms suggests that holding other factors constant, a $10 \%$ increase in the cash flow ratio $C F / K$ of private firms raises investment by about $0.7 \%$. Using a standardized impact approach, we can compute that a one standard deviation increase over the mean in the cash flow ratio $\mathrm{CF} / \mathrm{K}$ of private firms $(1.52=0.105 / 0.069$, cf. Table 1$)$ raises investment by $10.5 \%$. Since the average investment rate over our sample is $15 \%$, this would mean an additional 1.5 percentage point increase which is economically significant.

In Table 3, we turn to alternative measures of internal finance as an additional robustness check. Following Whited (1992), Harrison and McMillan (2003), we use the ratio of "total liabilities over total assets" as a firm-level measure of financial distress. The "liability to asset" ratio can be interpreted as both a measure of the firm's lack of collateral and a measure of the firm's current

\footnotetext{
${ }^{20}$ Another potential concern is the difficulty to properly account for firm specific investment opportunity. So far they were approximated by the change in turnover over capital (between $t_{-} 1$ and $t$ ), which is likely to be a poor proxy. Firm fixed effects (together with time-varying sector level fixed effects) should mitigate the issue. In any case, we checked that our results were robust to the use of alternative proxies. We relied on the change in turnover over capital as well as the change in sales over capital over different periods (between $t_{-} 1$ and $\mathrm{t}$ as well as between $t$ and $t+1$ ). Results available upon request confirm our main findings.

${ }^{21}$ The inclusion of firm-level fixed effects together with a lagged dependent variable can render the coefficients biased and inconsistent. Nickell (1981) shows that the bias approaches 0 as the sample size tends to infinity.

${ }_{22}$ Firms with a higher level of cash flow are supposed to depend more on their internal generated funds, which implies that the degree of financial constraints is increasing the size of the cash flow dependency. In the literature, non-linearity in financial constraints is more often apprehended using the quadratic term of the lagged dependent variable in parallel to the lagged dependent variable (Harrison and Love et al., 2004; Hubbard, 1998). In order to check that our results are robust to this alternative way of accounting for non-linearity in the cash flow investment sensitivity we rerun our regression including both the cash flow squared and the lagged dependent variable. Our results (unreported but available upon request) attest to the robustness of our findings.

${ }^{23}$ We claim that controlling for non-linearity in the cash flow sensitivity strengthens the paper findings of significant conditional impact of cash flow sensitivity depending on SOE or foreign presence.
} 
demand for borrowing relative to its capacity to borrow. Similar to Harrison and McMillan (2003) and Héricourt and Poncet (2008), we anticipate that credit constrained firms display a negative sensitivity of investment to our proxy of financial distress.

As expected, we find the coefficient on "total liabilities to assets" to be negative (and highly significant) only for private companies, meaning that high existing liabilities in terms of total assets indeed reduce the firm's capacity to invest.

The results with respect to the liability-asset ratio of private firms contrast strongly with those on other type of firms where this ratio, our proxy for financial distress, does not affect the public companies' and foreign companies' investment. Our findings suggest that the documented abundance of alternative and informal financing channels did not succeed to solve entirely private firms' credit constraints.

For the SOE firms in China we interpret this as evidence in support of the notion of a soft budget constraints (Qian and Roland, 1998; Konings and Vandenbussche, 2004) where irrespective of their indebtedness, state-owned firms still find the financial means outside the firm to engage in investment. For foreign firms, the irrelevance of firm-level indebtedness for investment purposes may be related to intra-group financial means at their disposal.

Since private firms (and not state-owned firms) are the engine role of growth in the Chinese economy, we move on to investigate whether there are some circumstances (related to FDI and state presence) that may modulate the effectiveness of the credit restrictions of private Chinese firms.

\section{Contingency of the relationship between investment and cash flow}

At the beginning of the 1980s, the Chinese government decided to gradually liberalize its regime for inward FDI by creating several "special economic zones" (SEZ) to attract foreign investment. ${ }^{24}$ In these zones foreign investment was encouraged through lower tax rates, fewer and simplified administrative and customs procedures and, most importantly, duty free import of components and suppliers (Naughton, 2007). As suggested by Huang (2003) and Luo (2007), imperfections in the banking sector in China may force private Chinese firms to look for foreign investors. By establishing cross-border relationships with foreign firms, private domestic firms can bypass both the credit market imperfections that they face at home. Hence, FDI can in fact be seen as a form of equity financing (Harrison et al., 2004). It is also possible that on top of that direct "capital injection" effect, indirect mechanisms are at work. More specifically, foreign firms present in China may extend more lenient trade credit financing to local firms in an attempt to create local customer networks, a phenomenon also described in other developing countries. This may further reduce the credit constraints faced by the local firms. ${ }^{25}$

Based on this we would expect that private Chinese firms face significantly lower financing constraints in provinces with a greater intensity of foreign direct investment. On the contrary, firms located in provinces where the FDI rates are low (like the northern and western provinces) are expected to have a higher sensitivity of investment to cash flow. This hypothesis should remain true even after controlling for the access to an alternative financing source in the form of trade credits.

To see whether the presence of FDI alleviates financial constraints for private Chinese firms in the same province, we use the basic specification of Eq. (7) and include the ratio of "trade credit over total assets" and variables measuring the importance of foreign investment, both as a main effect and interacted with our proxy for credit constraints.

Along similar lines, it can be argued that state presence in a province may have the opposite effect and may aggravate credit constraints for private Chinese firms caused amongst others by banks preference to lend to state-owned enterprises.

To evaluate whether foreign investment in China and state presence affect the magnitude of credit constraints, we use three types of measurements. ${ }^{26} \mathrm{~A}$ first set of indicators are traditional province-level indicators of the abundance of foreign capital and of the relative size of the state corporate sector: the ratio of FDI over GDP and the ratio of employment in state-owned firms over total employment respectively. Both indicators are taken from the China Statistical Yearbooks (2009). A second set of measures rely on information of the fixed asset investment by source of financing. Typically the source of financing is broken down into domestic loans, state budgetary appropriation, foreign investment, and self-raised funds. ${ }^{27}$ We use the "share of fixed assets investment financed by foreign sources" as a proxy of foreign capital and the "share of fixed assets investment financed by the state budget" as a proxy for state presence.

A third set of indicators relies on Oriana data to measure the importance of the foreign and state sector. We use four alternative size measures by looking at tangible assets, total assets, turnover and sales carried out by foreign firms versus state firms respectively at the province $p$ and sector (2-digit) $k$ level as follows:

$$
F D I_{p k, t}=\frac{\sum_{i} X_{i, p k, t} * \text { Foreign_Firm }}{i, p k, t}
$$

\footnotetext{
${ }^{24}$ SEZs are entitled to set their own policies and allowed to have a more liberal economic law than the country's one.

${ }^{25}$ We thank an anonymous referee for this remark.

${ }^{26}$ Ideally we would need to have detailed information on ownership changes over time. However, the data limitation that we face is that we have information on ownership structure but only for the first year a firm enters the dataset.

27 Domestic loans include funds borrowed from domestic banks and non-bank financial institutions by local enterprises and institutions. State budgetary appropriation consists essentially of appropriation in the government budget earmarked for capital construction and infrastructure projects. Foreign investment refers to foreign funds in fixed assets, foreign funds borrowed and managed by the government or by individual units, as well as foreign funds in joint-ventures. Self-raised funds include funds raised by various types of enterprises through non-state channels such as bonds, stocks, venture capital, and retained earnings. These data come from the China Statistical Yearbooks.
} 
where Foreign_Firm $i, p k, t$ is a dummy that equals 1 when firm $i$ is foreign and $X_{i, p k, t}$ denotes the different variables: tangible assets, total assets, turnover or sales.

Symmetrically, we measure the importance of state-owned corporate sector at the province $p$ and sector (2-digit) $k$ level as:

$$
\text { State }_{p k, t}=\frac{\sum_{i} X_{i, p k, t} * \text { State_Firm }_{i, p k, t}}{\sum_{i} X_{i, p k, t}}
$$

where State_Firm $\mathrm{i}_{\mathrm{i}, p k, t}$ is a dummy that equals 1 when firm $i$ is state-owned and $X_{i, p k, t}$ denotes the different variables: tangible assets, total assets, turnover or sales.

After defining the measures above, our purpose is to analyze their interactions with the cash flow variable in our baseline specification in Eq. (7). Since our proxies of foreign investment and state presence are introduced in a our preferred specification including firm-level fixed effects, their conditioning impact on credit constraints will be identified through the time dimension of the data. We believe that our estimates are unlikely to suffer from reverse causality as our indicators of foreign investment and state importance are computed at the province $p$ and sector (2-digit) $k$ level while the explained variable is firm specific. It is indeed unlikely that a firm shock translates into a change in province-industry level of foreign or state presence. ${ }^{28}$

Table 4 reports results on all the separate indicators that proxy for the abundance of foreign capital at the provincial and province/sector level.

Columns 1 to 6 introduce successively various indicators of province-level foreign capital (share of fixed assets investment financed by foreign sources; ratio of FDI over GDP; share of foreign enterprises in tangible assets; in total assets; in turnover and in sales). Our wide set of indicators allows us to account for different aspects of the foreign presence and to test the robustness of our results.

Almost all specifications in Table 4 suggest that FDI eases Chinese private firms' credit constraints, as compared to estimates from the specification including only the cash flow term $(\mathrm{CF} / \mathrm{K})$, in Table 2 column (Eq. (7)). The coefficients on the interaction terms, $\mathrm{CF} / \mathrm{K}$ times our proxies for foreign capital, are almost all negative and significant for private firms. At the same time, firm's cash flow sensitivity to investment is decreasing significantly with a higher share of "trade credit over assets". Even though trade credit acts like an alternative financing source, the presence of foreign firms is still reducing credit constraints for private firms.

Furthermore, it is unlikely that this FDI-mitigation of credit constraints is an artifact due to the endogenous location choice process of foreign firms which localize especially in regions where credit constraints are limited. Indeed empirical results on the importance of local bank lending practices as determinants of FDI location suggest that FDI mainly flows into regions characterized by imperfections in the banking sector and state investment policies (Havrylchyk \& Poncet, 2007).

Our findings that FDI inflows are positively related to the restricted access to external funding by private enterprises, suggests there is no evidence of foreign capital crowding out private capital in China. This finding is in line with that of Harrison and Love et al. (2004) from a cross-country firm-level panel. They showed that FDI flows are associated with a reduction in firm-level financing constraints. However it contrasts with the results of Harrison and McMillan (2003) on the Ivory Coast data, where the presence of foreign firms crowds local firms out of domestic capital markets. These diverging results highlight differences in financial sector organization and practice across countries. As suggested in Harrison and McMillan (2003), Côte d'Ivoire is very peculiar in the sense that foreign firms borrow heavily on domestic credit markets. The authors suggest that local banks found lending to foreign enterprises less costly because they were generally considered less risky and more profitable than domestic firms. Thus, financing constraints of domestic firms in Côte d'Ivoire were exacerbated by the presence of foreign firms, which benefited from a preferential treatment from domestic credit markets. In China the situation appears different. While in our data there is no information available on how foreign firms and domestic firms finance their operations in China, in the World Bank investment climate survey (2003) the proportion of Chinese firms that declare to have a bank loan is about $22 \%$ irrespective of the degree of foreign ownership of the Chinese firm. This suggests that in China, as opposed to Côte d'Ivoire, foreign firms do not appear to borrow more heavily on (domestic) credit markets. If anything, it seems that they rely to a greater extent on foreign financing sources. Another question in the World Bank survey involves "the share of a firm's total borrowing (loans and accounts payable) denominated in foreign currency". The responses show that foreign ownership indeed has an impact on the share of loans that is a denominated in foreign currency i.e. $18.6 \%$ for $100 \%$ foreign firms, $7.3 \%$ for firms with $50 \%$ foreign capital and $1.8 \%$ for firms with $0 \%$ foreign capital on average. ${ }^{29}$ These statistics indicate that while foreign firms in China rely much less on domestic capital markets compared to domestic Chinese firms. This is consistent with the fact that we do not observe any crowding out effect of foreign capital on domestic Chinese firms. The results rather indicate that abundance of foreign capital alleviate existing financial distortions that may otherwise constitute an impediment for private firms' economic activity.

In addition we also look at the presence of the state-owned corporate firms which may also be a conditioning factor of the effectiveness of private firms' credit constraints in China. Huang (2003) cites anecdotal evidence that the degree of the pecking order for credit may differ among locations/industries. For example, the political pecking order in the Garment industry, one of the few industries private entrepreneurs can enter relatively freely, is argued to be characterized by stronger credit constraints for private firms than in other industries. Also, if a private firm competes directly with a state-owned firm in the same industry the chances to get a loan diminish substantially. If the conjecture by Huang (2003) is correct, then one should see that it is more difficult for private firms, to have access to credit in provinces/sectors where the relative size of the state-owned corporate sector is

\footnotetext{
28 When the dependent variable is at the finest level possible, shocks in the error term will be less likely to affect the right-hand side variables. Moreover, if the explanatory variables are more aggregated, endogeneity is again less likely since shocks to individual variables affect regional variables only slightly.

29 No information exists on the extent to which foreign firms are financed by means of their mother company abroad.
} 


\section{Table 4}

Estimation of investment to cash flow sensitivities depending on the share of foreign direct investment for private Chinese firms.

\begin{tabular}{|c|c|c|c|c|c|c|}
\hline & (1) & (2) & (3) & (4) & (5) & (6) \\
\hline $\begin{array}{l}\text { Lagged dependent var } i, t-1 \\
\quad \text { (investment divided by lagged total assets) }\end{array}$ & $\begin{array}{l}-0.310^{*} \\
(0.025)\end{array}$ & $\begin{array}{l}-0.416^{*} \\
(0.034)\end{array}$ & $\begin{array}{l}-0.432^{*} \\
(0.034)\end{array}$ & $\begin{array}{l}-0.311^{*} \\
(0.025)\end{array}$ & $\begin{array}{l}-0.311^{*} \\
(0.025)\end{array}$ & $\begin{array}{l}-0.309^{*} \\
(0.025)\end{array}$ \\
\hline Change in turnover over assets $i, t$ & $\begin{array}{l}0.033^{*} \\
(0.007)\end{array}$ & $\begin{array}{l}0.029^{*} \\
(0.010)\end{array}$ & $\begin{array}{l}0.026^{* *} \\
(0.010)\end{array}$ & $\begin{array}{l}0.034^{*} \\
(0.007)\end{array}$ & $\begin{array}{l}0.033^{*} \\
(0.007)\end{array}$ & $\begin{array}{l}0.033^{*} \\
(0.007)\end{array}$ \\
\hline Cash flow over assets $i, t-1$ & $\begin{array}{l}0.221^{*} \\
(0.062)\end{array}$ & $\begin{array}{l}0.346^{*} \\
(0.092)\end{array}$ & $\begin{array}{l}0.377^{*} \\
(0.098)\end{array}$ & $\begin{array}{l}0.219^{*} \\
(0.057)\end{array}$ & $\begin{array}{l}0.217^{*} \\
(0.058)\end{array}$ & $\begin{array}{l}0.213^{*} \\
(0.058)\end{array}$ \\
\hline Employment over assets $i, t$ & $\begin{array}{l}-2.755 \\
(2.316)\end{array}$ & $\begin{array}{l}-1.800 \\
(2.827)\end{array}$ & $\begin{array}{l}-2.325 \\
(2.810)\end{array}$ & $\begin{array}{l}-2.529 \\
(2.314)\end{array}$ & $\begin{array}{l}-2.632 \\
(2.314)\end{array}$ & $\begin{array}{l}-2.663 \\
(2.315)\end{array}$ \\
\hline Cash flow over assets squared $i, t$ & $\begin{array}{l}0.104 \\
(0.078)\end{array}$ & $\begin{array}{l}0.297^{* * *} \\
(0.129)\end{array}$ & $\begin{array}{l}0.320^{* *} \\
(0.129)\end{array}$ & $\begin{array}{l}0.093 \\
(0.078)\end{array}$ & $\begin{array}{l}0.096 \\
(0.078)\end{array}$ & $\begin{array}{l}0.100 \\
(0.078)\end{array}$ \\
\hline Trade credit over total assets $i, t-1$ & $\begin{array}{l}0.132^{* * * *} \\
(0.070)\end{array}$ & $\begin{array}{l}0.120 \\
(0.123)\end{array}$ & $\begin{array}{l}0.134 \\
(0.124)\end{array}$ & $\begin{array}{l}0.143^{* * *} \\
(0.075)\end{array}$ & $\begin{array}{l}0.142^{* * *} \\
(0.076)\end{array}$ & $\begin{array}{l}0.139^{* * *} \\
(0.076)\end{array}$ \\
\hline Cash flow trade credit over assets $i, t-1$ & $\begin{array}{l}-0.041^{* * *} \\
(0.021)\end{array}$ & $\begin{array}{l}-0.028^{* *} \\
(0.010)\end{array}$ & $\begin{array}{l}-0.096 \\
(0.055)\end{array}$ & $\begin{array}{l}-0.104^{* *} \\
(0.035)\end{array}$ & $\begin{array}{l}-0.115^{* * *} \\
(0.057)\end{array}$ & $\begin{array}{l}-0.115^{* * *} \\
(0.059)\end{array}$ \\
\hline $\begin{array}{l}\text { Province level share of foreign fixed asset investment } \\
\text { Source CSY } i, t \\
\text { Interaction with cash flow } i, t\end{array}$ & $\begin{array}{l}-0.067 \\
(0.207) \\
-0.296 \\
(0.145)\end{array}$ & & & & & \\
\hline $\begin{array}{l}\text { Province level FDI/gdp } \\
\text { Source CSY } i, t \\
\text { Interaction with cash flow } i, t\end{array}$ & & $\begin{array}{l}-0.003 \\
(0.002) \\
-0.254 \\
(0.204)\end{array}$ & & & & \\
\hline $\begin{array}{l}\text { Share of foreign enterprises in tangible assets } \\
\text { Source Oriana } i, t \\
\text { Interaction with cash flow } i, t\end{array}$ & & & $\begin{array}{l}0.013 \\
(0.128) \\
-0.267 * * \\
(0.123)\end{array}$ & & & \\
\hline $\begin{array}{l}\text { Share of foreign enterprises in total assets } \\
\text { Source Oriana } \mathrm{i}, \mathrm{t} \\
\text { Interaction with cash flow } i, t\end{array}$ & & & & $\begin{array}{l}-0.075 \\
(0.063) \\
-0.253^{* * *} \\
(0.124)\end{array}$ & & \\
\hline $\begin{array}{l}\text { Share of foreign enterprises in turnover } \\
\text { Source Oriana } i, t \\
\text { Interaction with cash flow } i, t\end{array}$ & & & & & $\begin{array}{l}0.036 \\
(0.053) \\
-0.239 \\
(0.101)\end{array}$ & \\
\hline $\begin{array}{l}\text { Share of foreign enterprises in sales } \\
\text { Source Oriana } i, t \\
\text { Interaction with cash flow } i, t\end{array}$ & & & & & & $\begin{array}{l}0.038 \\
(0.054) \\
-0.242^{* *} \\
(0.109)\end{array}$ \\
\hline Sector (2 digits)-year fixed effects & Yes & Yes & Yes & Yes & Yes & Yes \\
\hline Observations & 4264 & 2393 & 4264 & 4264 & 4264 & 4264 \\
\hline Number of id & 2690 & 1567 & 2690 & 2690 & 2690 & 2690 \\
\hline$R$-squared & 0.120 & 0.193 & 0.122 & 0.121 & 0.120 & 0.120 \\
\hline
\end{tabular}

Standard errors in parentheses.

CSY: Chinese Statistical Yearbook.

Oriana: firm-level database from which we aggregated variables like province/sector tangible assets, total assets, turnover and sales.

* Significant at $1 \%$.

** Significant at $5 \%$.

*** Significant at $10 \%$.

high. We thus expect that private firms have a higher sensitivity of investment to cash flow i.e. are more financially constrained, in locations/industries where the state presence is high.

Again we also include "trade credit to total assets" together with an interaction term of trade credit and cash flow as additional control variables.

Table 5 confirms that the effect of the political pecking order of firms on external finance costs of private firms is conditional on the relative size of the state-owned corporate sector. In columns 1 through 6 , a variable measuring the importance of state presence is included to the baseline specification, both as a main effect and interacted with our proxy for credit constraints. We use each of the 6 indicators presented earlier to proxy for the size of the state sector at the provincial and province/sector level. In columns 2 and 3, we use indicators built at the province level with data taken from the China statistical yearbook measuring the "province-level share of employment in state units" and the "share of investment financed by state budget over total investment". In columns 4 to 7, we rely on proxies computed from the Oriana dataset of the "state share in tangible assets, total assets, turnover and sales" by province and sector.

Table 5 shows that in most cases (especially using proxies based on the Oriana dataset), the interaction of cash flow and proxies for the presence of the state sector is positive and significant. On the other hand, trade credit interacted with cash flow is negative and significant in all specifications. This suggests that when trade credit is present as an alternative financing source, it reduces financial constraints for private firms. But at the same time a greater size of the state-owned corporate sector amplifies credit 
Table 5

Estimation of investment to cash flow sensitivities depending on the share of state-owned firms per industry for private Chinese firms.

\begin{tabular}{|c|c|c|c|c|c|c|}
\hline & $(1)$ & $(2)$ & (3) & $(4)$ & (5) & (6) \\
\hline $\begin{array}{l}\text { Lag dependent } i, t-1 \\
\quad \text { (investment divided by lagged total assets) }\end{array}$ & $\begin{array}{l}-0.310^{*} \\
(0.025)\end{array}$ & $\begin{array}{l}-0.308^{*} \\
(0.025)\end{array}$ & $\begin{array}{l}-0.309^{*} \\
(0.025)\end{array}$ & $\begin{array}{l}-0.309^{*} \\
(0.025)\end{array}$ & $\begin{array}{l}-0.307^{*} \\
(0.025)\end{array}$ & $\begin{array}{l}-0.307^{*} \\
(0.025)\end{array}$ \\
\hline Change in turnover over assets $i, t$ & $\begin{array}{l}0.032^{*} \\
(0.007)\end{array}$ & $\begin{array}{l}0.032^{*} \\
(0.007)\end{array}$ & $\begin{array}{l}0.033^{*} \\
(0.007)\end{array}$ & $\begin{array}{l}0.033^{*} \\
(0.007)\end{array}$ & $\begin{array}{l}0.034^{*} \\
(0.007)\end{array}$ & $\begin{array}{l}0.034^{*} \\
(0.007)\end{array}$ \\
\hline Cash flow over assets $i, t-1$ & $\begin{array}{l}0.252^{*} \\
(0.076)\end{array}$ & $\begin{array}{l}0.227^{*} \\
(0.064)\end{array}$ & $\begin{array}{l}0.230 * \\
(0.064)\end{array}$ & $\begin{array}{l}0.220^{*} \\
(0.063)\end{array}$ & $\begin{array}{l}0.217^{*} \\
(0.062)\end{array}$ & $\begin{array}{l}0.219^{*} \\
(0.062)\end{array}$ \\
\hline Employment over assets $i, t$ & $\begin{array}{l}-3.365 \\
(2.296)\end{array}$ & $\begin{array}{l}-2.999 \\
(2.304)\end{array}$ & $\begin{array}{l}-2.753 \\
(2.298)\end{array}$ & $\begin{array}{l}-2.708 \\
(2.298)\end{array}$ & $\begin{array}{l}-2.683 \\
(2.297)\end{array}$ & $\begin{array}{l}-2.694 \\
(2.297)\end{array}$ \\
\hline Cash flow over assets squared $i, t$ & $\begin{array}{l}0.104 \\
(0.080)\end{array}$ & $\begin{array}{l}0.116 \\
(0.081)\end{array}$ & $\begin{array}{l}0.079 \\
(0.080)\end{array}$ & $\begin{array}{l}0.072 \\
(0.080)\end{array}$ & $\begin{array}{l}0.068 \\
(0.080)\end{array}$ & $\begin{array}{l}0.069 \\
(0.080)\end{array}$ \\
\hline Trade credit over total assets $i, t-1$ & $\begin{array}{l}0.005 \\
(0.075)\end{array}$ & $\begin{array}{l}-0.002 \\
(0.075)\end{array}$ & $\begin{array}{l}-0.023 \\
(0.075)\end{array}$ & $\begin{array}{l}-0.021 \\
(0.075)\end{array}$ & $\begin{array}{l}-0.022 \\
(0.075)\end{array}$ & $\begin{array}{l}-0.022 \\
(0.075)\end{array}$ \\
\hline Cash flow trade credit over assets $i, t-1$ & $\begin{array}{l}-0.490^{* * *} \\
(0.240)\end{array}$ & $\begin{array}{l}-0.541 \\
(0.304)\end{array}$ & $\begin{array}{l}-0.511^{* * *} \\
(0.314)\end{array}$ & $\begin{array}{l}-0.573^{* * *} \\
(0.343)\end{array}$ & $\begin{array}{l}-0.599^{* * *} \\
(0.343)\end{array}$ & $\begin{array}{l}-0.586^{* * *} \\
(0.343)\end{array}$ \\
\hline $\begin{array}{l}\text { Province level state share of employment } \\
\text { Source CSY } i, t \\
\text { Interaction with cash flow } i, t\end{array}$ & $\begin{array}{l}0.218 \\
(0.247) \\
0.118 * * \\
(0.059)\end{array}$ & & & & & \\
\hline $\begin{array}{l}\text { Province level share of investment financed by state budget } \\
\text { Source CSY } i, t \\
\text { Interaction with cash flow } i, t\end{array}$ & & $\begin{array}{l}0.365 \\
(0.336) \\
0.157^{* * *} \\
(0.087)\end{array}$ & & & & \\
\hline $\begin{array}{l}\text { Share of state enterprises in tangible assets } \\
\text { Source Oriana } i, t \\
\text { Interaction with cash flow } i, t\end{array}$ & & & $\begin{array}{l}0.027 \\
(0.050) \\
0.063 \\
(0.330)\end{array}$ & & & \\
\hline $\begin{array}{l}\text { Share of state enterprises in total assets } \\
\text { Source Oriana } i, t \\
\text { Interaction with cash flow } i, t\end{array}$ & & & & $\begin{array}{l}0.034 \\
(0.055) \\
0.205^{*} \\
(0.065)\end{array}$ & & \\
\hline $\begin{array}{l}\text { Share of state enterprises in turnover } \\
\text { Source Oriana } i, t \\
\text { Interaction with cash flow } i, t\end{array}$ & & & & & $\begin{array}{l}0.071 \\
(0.057) \\
0.245^{*} \\
(0.086)\end{array}$ & \\
\hline $\begin{array}{l}\text { Share of state enterprises in sales } \\
\text { Source Oriana } i, t \\
\text { Interaction with cash flow } i, t\end{array}$ & & & & & & $\begin{array}{l}0.067 \\
(0.057) \\
0.274^{*} \\
(0.087)\end{array}$ \\
\hline Sector (2 digits)-year fixed effects & Yes & Yes & Yes & Yes & Yes & Yes \\
\hline Observations & 4309 & 4309 & 4309 & 4309 & 4309 & 4309 \\
\hline Number of id & 2717 & 2717 & 2717 & 2717 & 2717 & 2717 \\
\hline$R$-squared & 0.128 & 0.124 & 0.122 & 0.122 & 0.123 & 0.123 \\
\hline
\end{tabular}

Standard errors in parentheses.

CSY: Chinese Statistical Yearbook.

Oriana: firm-level database from which we aggregated variables like province/sector tangible assets, total assets, turnover and sales.

* Significant at $1 \%$.

** Significant at $10 \%$.

*** Significant at $5 \%$.

constraints for private firms. Thus, the results confirm our prediction that the severeness of credit constraints for private Chinese firms is worse in industries with a high share of state-owned enterprises even though firms have access to an alternative financing source in the form of trade credit.

This micro-level evidence is coherent with macro-level findings of Guariglia et al. (2008) and Boyreau-Debray and Wei (2005).

These results suggest that privatization and the further reduction of the state-owned corporate sector in China is likely to boost the investment and growth of private firms.

\section{Conclusion}

This paper investigates both the magnitude and the conditioning factors of credit allocation to Chinese firms by ownership type. To identify credit constraints we follow the investment literature pioneered by Fazzari et al. (1988) by examining the extent to which Chinese firms' investment is affected by the availability of internal finance.

The results over the period 1998-2005 suggest that private Chinese firms face severe financial constraints while we find no such constraints for state-owned and foreign enterprises. This finding is at odds with the observation that private Chinese firms are the engine of growth in the Chinese economy. 
We subsequently study the circumstances under which existing capital market distortions in China may not represent an impediment to economic activity. We test two conditioning factors of the severeness of private firms' credit constraints: (1) the geographical and industrial presence of FDI in China and (2) the size of the state-owned corporate sector. We identify FDI as an important mechanism for private Chinese firms to overcome financial constraints. Our results suggest that the presence of FDI eases financing constraints and spurs growth and investment of private firms. In contrast, the size of the state-owned corporate sector negatively affects the extent to which private Chinese firms' investment depends on internal finance. Financing constraints are found to be increasing with the relative size of the state sector. Private Chinese firms competing directly with numerous stateowned enterprises in the same province/industry depend more strongly on their internal generated funds for their investment and appear more credit constraint which impedes their growth.

Our findings allow us to predict the likely beneficial impact of the ongoing reforms inducing further liberalization to foreign capital and state firms restructuring on the economic dynamism of the Chinese economy. Existing capital market imperfections in China for private firms are likely to be mitigated by the growing importance of foreign firms in the Chinese economy as well as the ongoing decline of the state economic predominance. Indeed, recent developments demonstrate a continuing shift away from state ownership. The China Economic Census Yearbook (2004) indicates declines of over 45\% in each of the two most prominent forms of public ownership, i.e. state-owned firms and collectives from 2000. In parallel, China has also experienced a fundamental change with regard to the means of allocating financial resources with its entry in the WTO in 2001 which involved amongst others a removal of restrictions on the activities of foreign banks. For this reason we can anticipate rapid changes in the Chinese allocation of credit in the future that reduce Chinese private firms' credit constraints.

\section{References}

Abraham F., J. Konings and V. Slootmaekers, (2007), FDI spillovers in the Chinese manufacturing sector: evidence of firm heterogeneity, CEPR Discussion Paper No. 6573, forthcoming in The Economics of Transition.

Aghion, P., Askenazy, P., \& Berman, N. (2008). Credit constraints and the cyclicality of R\&D investment: Evidence from France. Harvard discussion paper.

Allayannis, Y., \& Muzomdar, A. (2004). The impact of negative cash-flows and influential observations on investment-cash flow sensitivity estimates. Journal of Banking and Finance, 28, 901-930.

Allen, F., Qian, J., \& Qian, M. (2005). Law, finance and economic growth in China. Journal of Financial Economics, 77, 57-116.

Almeida, H., \& Campello, M. (2006). Financial constraints, asset tangibility and corporate investment. NBER Working Papers (pp. 12087).

Alti, A. (2003). How sensitive is investment to cash flow when financing is frictionless. Journal of Finance, 58(2), 707-722.

Beck, T. Demirguc-Kunt, A. \& Maksimovic, V. (2005). Financial and legal constraints to firm growth: Does size matter? The Journal of Finance, 60, 1(02), 137-177.

Bond, S., \& Meghir, C. (1994). Dynamic investment models and the firm's financing policy. Review of Economic Studies, 61(2), $197-222$.

Boyreau-Debray, G., \& Wei, S. -J. (2005). Pitfalls of a state-dominated financial system: The case of China. NBER Working Paper 11214.

Carpenter, R. E., \& Petersen, B. (2002). Is growth of small firms constrained by internal finance? The Review of Economics and Statistics, 84(2), 298-309.

China Economic Census Yearbook (2004). National Bureau of Statistics of China, China Statistics Press.

China Statistical Yearbook (2009). National Bureau of Statistics of China, China Statistics Press.

Fazzari, S., Hubbard, G., \& Petersen, B. (1988a). Financing constraints and corporate investment. Brookings Papers on Economic Activity, 19,141 -195.

Fazzari, S., Hubbard, G., \& Petersen, B. (1988b). Investment, financing decisions and tax policy. American Economic Review, 78, $200-219$.

Fazzari, S., Hubbard, G., \& Petersen, B. (2000). Investment cash flow sensitivities are useful: A comment on Kaplan and Zingales. Quarterly Journal of Economics, 115 (2), 695-712.

Gomes, J. F. (2001). Financing investment. American Economic Review, 91(5), 1263-1285.

Guariglia, A., X. Liu and L. Song (2008), Is the growth of Chinese firms constrained by internal finance, mimeo.

Guariglia, A., \& Poncet, S. (2008). Could financial distortions be no impediment to economic growth after all? Evidence from China. Journal of Comparative Economics, 36(4), 633-657.

Hansen, H., \& Tarp, F. (2001). Aid and growth regressions. Journal of Development Economics, 64(2), 547-570.

Harrison, A., \& McMillan, M. (2003). Does direct foreign investment affect domestic firm credit constraints? Journal of International Economics, 61(1), 73-100.

Harrison, A., Love, \& McMillan, M. (2004). Global capital flows and financing constraints. Journal of Development Economics, 75, $269-301$.

Havrylchyk, O., \& Poncet, S. (2007). Foreign direct investment in China: Reward or remedy? The World Economy, 30(11), 1662-1681.

Héricourt, J., and S. Poncet (2008), FDI and credit constraints: Firm level evidence from China, forthcoming Economic Systems.

Huang, Y. (2003). Selling China (pp. 207). : Cambridge University Press.

Hubbard, R. G. (1998). Capital market imperfections and investment. Journal of Economic Literature, 36(1), $193-225$.

Huyghebaert, N., Quan, Q., \& Sun, L. (2006). Financing decisions in newly privatized Chinese firms: Does a stock market quotation really provide disciplining. KUL Working paper.

Javorcik, B., \& Spatareanu, M. (2008). Liquidity constraints with multinationals. LICOS discussion paper 225/2008. : KUleuven.

Kaplan, S., \& Zingales, L. (1997). Do investment-cash flow sensitivities provide useful measures of financing constraints? Quarterly Journal of Economics, 112(1), $169-215$.

Konings, J., \& Vandenbussche, H. (2004). The adjustment of financial ratios in the presence of soft budget constraints: Evidence from Bulgaria. European Accounting Review, $1-16$

Konings, J., Rizov, M., \& Vandenbussche, H. (2003). Investment constraints in transition countries. Economic Letters, 78(2), $253-258$.

Lizal, L., \& Svejnar, J. (2002). Investment, credit rationing and the soft budget constraint: Evidence from Czech panel data. The Review of Economics and Statistics, 84 (2), 353-370.

Love, I. (2003). Financial development and financing constraints: International evidence from the structural investment model. Review of Financial Studies, 16, $765-791$.

Luo, C., (2007). FDI: a visible hand. Mimeograph. Center for European Studies \& China Center for Economic Studies. Fudan University, Shanghai, China.

Modigliani, F., \& Miller, M. H. (1958). The cost of capital, corporation finance and the theory of investment. American Economic Review, 48 (3), $261-297$.

Naughton, B. (2007). The Chinese economy: Transition and growth (pp. 332). : MIT Press.

Nickell, S. (1981). Biases in dynamic models with fixed effects. Econometrica, 49, 1417-1426.

ORIANA (2009). Oriana - Chinese firm level database. Bureau van Dijk Electronic Publishing.

Qian, Y., \& Roland, G. (1998). Federalism and the soft budget constraint. American Economic Review, 88(5), 1143-1162.

Staiger, D., \& Stock, J. H. (1997). Instrumental Variables Regression with Weak Instruments. Econometrica, Econometric Society, 65(3), 557-586.

Stein, J. (2003). Agency, Information and Corporate Investment. In George Constantinides, Milt Harris, \& Rene Stulz (Eds.), Handbook of the Economics of Finance. Amsterdam: North Holland.

Stock, J. H., \& Yogo, M. (2002). Testing for weak instruments in linear IV regression. NBER technical working paper 284.

Whited, T. (1992). Debt, liquidity constraints, and corporate investment: Evidence from panel data. Journal of Finance, 47(4), $1425-1460$. 